\section{Revista de Investigación en Logopedia} ISSN: 1131-8635

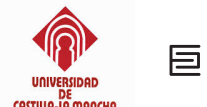

\title{
Multidisciplinary approach in a case of hemifacial microsomia: Speech and language pathologist contributions
}

\author{
Cristina Peris Hernández'; Vicent Rosell ${ }^{2}$
}

Recibido: 21 de agosto de 2018 / Revisado: 18 de octubre 2018 / Aceptado: 17 de noviembre 2018

\begin{abstract}
This study shows the initial pathology, the evolution and the treatment of a clinical case of Hemifacial Microsomia from childhood to adolescence, placing special emphasis on the approach of the case from the point of view of Speech and language pathology. The objective of this research was to show the performances of the speech pathologist at the level of evaluation and rehabilitation of the functional alterations involved: respiration, chewing and speech. The methodology used was that of the case study, for which purpose it was decided to chronologically present the instruments and measures used, as well as the interventions carried out in three phases: from 0 to 4 years, from 5 to 11 and from 12 to 16 years. The results show the favorable evolution of the patient in the acquisition and maintenance of a pattern of nasal breathing, which includes the correct placement of the tongue at rest, the acquisition of a pattern of alternating bilateral chewing and a remarkable improvement in the quantity and quality of masticatory cycles, as well as the normalization of labial competence and the elimination of noises during swallowing. On the other hand, in the rehabilitative treatment performed after the arthroplasty, positive results were also recorded in the range of mandibular movement at the vertical and lateral levels, restoring retrusion. Therefore, we concluded that speech and language intervention was beneficial both in the rehabilitation of the functions and in the aesthetic changes at the level of the orofacial structures.
\end{abstract}

Key words: Hemifacial Microsomia; myofunctional disorders; myofunctional therapy, relapse.

\section{[es] Aproximación multidisciplinar en un caso de microsomía hemifacial: contribución de la logopedia}

Resumen. En el presente trabajo se expone la patología inicial, la evolución y el tratamiento de un caso clínico de Microsomía Hemifacial desde la infancia hasta la adolescencia, poniendo especial énfasis en el abordaje del caso desde el punto de vista de la Logopedia. El objetivo de esta investigación fue mostrar las actuaciones del logopeda a nivel de evaluación y rehabilitación de las alteraciones funcionales involucradas: respiración, masticación y habla. La metodología empleada fue la del estudio de caso, para ello, se decidió presentar cronológicamente los instrumentos y medidas utilizados, así como las intervenciones realizadas en tres fases: de 0 a 4 años, de 5 a 11 y de 12 a 16 años. Los resultados muestran la evolución favorable de la paciente en la adquisición y mantenimiento de un patrón de respiración nasal, que incluye la correcta colocación de la lengua en reposo, la adquisición de un patrón de masticación bilateral alternado y una mejora notable en la cantidad y calidad de los ciclos masticatorios, así como la normalización de la competencia labial y la eliminación de ruidos durante la deglución. Por otra parte, en el tratamiento rehabilitador realizado tras la artroplastia, se registraron también resultados

\footnotetext{
1 Clínica de Logopèdia de la Fundació Lluís Alcanyís

Universitat de València

cristina.peris-hernandez@fundacions.uv.es

2 Clínica de Logopèdia de la Fundació Lluís Alcanyís

Universitat de València
} 
positivos en el rango de movimiento mandibular a nivel vertical y lateral, restableciéndose la retrusión. Por tanto, concluimos que la intervención logopédica resultó beneficiosa tanto en la rehabilitación de las funciones como en los cambios estéticos a nivel de las estructuras orofaciales.

Palabras clave: Microsomia Hemifacial; alteraciones miofuncionales; terapia miofuncional; recivida.

Cómo citar: Peris Hernández, C.; Rosell, V. (2019). Multidisciplinary approach in a case of hemifacial microsomia: Speech and language pathologist contributions. Revista de Investigación en Logopedia, 8(1), $17-27$.

\section{Introduction}

Craniofacial syndromes, including Hemifacial Microsomia (HFM), are part of a group of complex and heterogeneous disorders that entail impairment of stomatognathic system functions, caused by dysmorphology located in the face and skull (Horgan, Padwa, Brie, \& Mulliken, 1995).

The diversity and variability of its clinical manifestations, as well as the lack of understanding of its pathogenesis, makes its classification very complex. There are several classifications that try to specify the anomalies present in the HFM by attending to the dysmorphologies in an isolated way (for example, only ear or jaw.), Or contemplating all the affected components. Among the best known is the SAT (Skeleton-Auricula-Tissues) classification, which focuses only on the evaluation of skeletal aspects, the affectation of the auricle and soft tissue (David, Mahatomarat and Cooter, 1987) or that of Pruzansky (1969) involving only the jaw and contemplating four types of affectation according to the severity of the dysmorphology: I mild, II moderate, IIB severe and III very severe, later modified by Mulliken and Kaban (1987). Other classifications focus on the global evaluation of all the components present in the HFM, such as OMENS (Vento, Labrie and Mulliken, 1991) and OMENS-PLUS (Horgan, Padwa, LaBrie and Mulliken, 1995) that represent the most complete attempt to evaluate the HFM, since they contemplate all the aspects immersed in the affectation of the patient, making possible the interchange of multidisciplinary information.

An orofacial mobility approach is particularly relevant in the treatment of myofunctional disorders appearing at early stages, contributing to the acquisition of certain respiratory and swallowing patterns, in both pre-and post-surgical periods. This clinical approach is geared at accelerating the recovery of the masticatory function, optimizing tissue condition and the muscles involved; in relation to anatomical structures, it enhances mobility recovery. The preventive work is aimed at avoiding recurrence and relapse.

\section{Description of the case study}

A 16-year-old woman who was born in the 42nd week of gestation and weighed $3.4103 \mathrm{~kg}$. As a new-born, her length was $49 \mathrm{~cm}$ and the cranial perimeter measured $35 \mathrm{~cm}$. Her Apgar score at 1': 09, while at 5 ': 10. The patient was diagnosed at 6 months of age with right unilateral Hemifacial Microsomia (HFM) presenting: Microtia type III, with right unilateral hearing loss of 70-80db, Micrognathia type III, macrostomy, moderate soft tissue involvement, hypertrofic adenoids and tonsils. 


\section{Method}

Considering that the case under study is a long-term multidisciplinary intervention procedure, we present the instruments and measurements used; furthermore, the measurements were carried out in three phases: from 0 to 4 , from 5 to 11 , and from 12 to 16 years, given that the needs for evaluation and treatment are different, according to the various stages of growth and the surgical interventions performed. Subsequently, the conclusive results are presented, comparing them with the initial state so that the evolution of the patient can be visualized.

\section{Stage 1: from 0 to 4 years}

The girl was referred to the maxillofacial clinic, for the evaluation and planning of the various reconstruction mandibular surgeries (bone graft, mandibular distractions and surgery for macrostomia correction); the patient also underwent plastic surgery for the reconstruction of the auricular pavilion. Her case was reviewed by the Otorhinolaryngology Department where a transmission hearing loss was diagnosed in the right ear, caused by the malformation in the ossicular chain of the middle ear, the atresia of the external auditory canal and the absence of the auricle (Microtia Type III). Hypertrophic tonsils and adenoids were also observed, but without clinical signs of sleep apnea (SAOS).

The girl began receiving speech therapy to stimulate auditory remains, while receiving the appropriate guidelines for the observation of language evolution, as well as for minimizing the risk of getting colds to prevent the accumulation of mucous in the healthy ear that could cause otitis.

A myofunctional approach with the chewing musculature was carried out with two purposes: the first to maintain the orofacial muscular balance and the second to improve the efficiency problems in swallowing of the patient, given the state of the muscles involved in mastication (Suzuki et al, 2017). Surgical procedures began at the age of 3 years (2001) with an adenoidectomy together with the placement of transtympanic drainage to avoid mucous accumulation in the middle ear that could interfere with the auditory process and to free the airway; this enabled speech therapy to take place at a later stage and helped to establish a correct nasal breathing pattern. At 4 years (2002) the mandibular reconstruction was started, with an iliac crest graft in the jaw since the patient lacked temporomandibular joint (TMJ) because it was a Pruzansy III, as explained in the introduction.

\section{Stage 2: 5 to 11 years}

In this second stage, three external osteogenic distractions took place, carried out at 5,7 and 11 years of age, which enabled the jaw to be elongated. The first one was performed in 2003, after consolidation of the bone graft performed one year before, taking advantage of macrostomy closure surgery. This distraction was unidirectional in a vertical sense, to elongate the consolidated bone graft.

The second distraction performed in 2006, at 7 years and 8 months of age, was carried out using a multidirectional external distractor. Six months before the orthodontic surgery a palate expander was placed after carrying out a bimaxillary cepha- 
lometric study, as well as a mandibular Tomography Axial Computer (CAT). After the distractions, the open bite was maintained by placing an acrylic block that was progressively reduced until the maxilla was lowered, as well as the adaptation of the teeth and the occlusal plane to the new bone situation. At the end of 2008, the speech therapist detected a progressive loss of mandibular opening, which led, after the appropriate radiological tests, to the diagnosis of an ankylosis of the TMJ by the maxillofacial service. In view of this development, it was decided to perform the last osteogenic distraction in October 2009, at the age of 11. The type of distraction selected was identical to the previous one, although the observed progress was not as expected, supposedly due to the joint restriction. At this stage, in the postoperative period of mandibular distractions, the speech therapist worked with the masticatory muscles to condition the tissues to the new bone formation, to gain volume and increase muscle mass in the buccinator and masseter respectively.

\section{Stage 3: 12 to 16 years}

The arthroplasty was performed in 2011, at 12 years and 7 months, under general anesthesia and nasotracheal intubation by fibroscope, given the impossibility of oral intubation. The surgery was performed by making a right temporo-preauricular incision in the anterior region where atrial reconstruction had already been performed and an ankvilotic block greater than $12 \mathrm{~mm}$ was released, after the forced dissection of the musculature with disimpactor and an interposing muscle graft: right temporal. After the arthroplasty the speech therapist carried out intensive treatment using mechanotherapy to recover an adequate opening. Finally, from October 2010 to January 2014, the patient underwent 5 operations to reconstruct the auricle -not yet concluded-, for which 3 costal cartilages were used on the right side, two on the left, as well as the temporal fascia to repair a partial necrosis. This prolonged reconstruction process of the auricular pavilion delayed, by indication of the plastic surgeon, the placement of an osseo-integrated implant. Therefore, the patient presents a monaural hearing and lacks auditory spatial orientation. However, the girl lives a completely normal life and is doing well at school. She does not present speech discrimination difficulties in noisy settings. However, preventive audiometric monitoring is being continued; furthermore, auditory remnants that are currently preserved have been stimulated and it has been decided to reconstruct the auricular pavilion using a vibrating pin attached to glasses.

Currently, the girl is 16 years old and still maintains a simple weekly orofacial motor program that has allowed her to reach the final stage of her reconstruction, with a reasonable result. In March 2015, she underwent a centering procedure and advancing mentoplasty to normalize her still retro-phantom profile and facial filling (lipofilling) to harmonize the facial oval, which together with the invisible orthodontics, will eventually provide her with an optimal aesthetic appearance until her full mandibular development has been completed around the age of 19 . 


\section{Intervention}

\section{Oral breathing}

Very early on, in the girl's first months of life, the family resorted to private speech therapy for suction-related problems; they also received the guidelines for good nasal and oral hygiene. Later, when upper airway obstruction was detected, the need for correct nasal hygiene was again indicated, as well as the importance of promoting recreational activities that favored the establishment of an adequate nasal breathing pattern. Glatzel mirror marks were obtained for the evaluation of nasal permeability. The respiratory type and the respiratory frequency were verified, as well as the heart rate. At the age of 3, the specialist who saw the patient due to the hearing deficit corroborated suspected adenoids and hypertrophic tonsils after videonasopharyngoscopy exploration and these were surgically removed. After the surgery, speech therapy was conducted by way of two 45-minute sessions weekly; During these sessions, the family was trained in: habits of nasal hygiene, the use during sleep of an oral screen that favor the emergence of an exclusively nasal pattern, games that strengthen the labial seal through isometric and isotonic exercises, using sets of scents that stimulate nasal sensitivity, the use of Otovent ${ }^{\circledR}$, to ventilate the middle ear and at the same time to work the nasal murmur, and the stimulation of the self-perception of the area. Postural control (verticality) and cervical relaxation through exercises and manual therapy were also encouraged. Activities that promote oral and nasal breathing were promoted. The modification of the respiratory type was also continued to encourage the establishment of a predominantly costodiaphragmatic type. Likewise, both the labial and lingual rest positions and the correct swallowing pattern were worked on (Borrás \& Rosell, 2006).

\section{Chewing-swallowing (efficacy)}

Coinciding with the start of mastication (7-12 months), myofunctional treatment was performed on the masticatory muscles since the girl quickly expressed fatigue with the consequent negative repercussions on general food intake. At 2.5 years of age, a functional assessment of mastication-swallowing was performed, in a natural context that tried to faithfully reflect her eating routine, where the speech therapist offered food and drink to the girl observing swallowing and mastication. The analytical global movements of the girl were mapped with the help of a fat-based dermatological marking pencil. In 2002, when the girl was 4 years old, a more objective evaluation was carried out, applying the Payne technique (Garliner, 1974), where the speech therapist offered a little water to the girl to moisten her oral cavity and then painted with a swab impregnated with fluorescein, the lateral edges of the tongue, the apex and the midline. Then he told her to swallow saliva and with a black light lamp the impacts left by the tongue when swallowing were observed (Ortiz, Restrepo and Sierra, 2011). To maintain the masticatory muscles of both sides as balanced as possible, we worked on the right muscles that were the ones least selected by the girl during her performance, through games involving very hard foods, textured teethers, In this table, the evolution of the facial measures recorded is monitored around 18-24 months after each mandibular distraction using king feet. 


\section{Chewing-Swallowing (Post arthroplasty - Efficacy)}

During the period in which the girl had ankylosis, chewing was seriously impaired since the limitation in the movements and the lack of openness prevented this function from being performed effectively; once this question was surgically resolved, a program was also started to improve her chewing musculature performance and focusing on her bilateral use; this occurred mainly during eating, which at that stage was a highly-motivating challenge for the girl. Later still, use was made of myofunctional chewing material, specific gums, textured teethers, and isometric exercises with and without counter-resistance were ordered.

\section{Soft tissue post-distraction osteogenesis}

The speech therapist, after each osteogenic distraction and the closing of the open bite, has carried out intensive work focused on the performance of isotonic and isometric exercises in the buccinator (of eccentric and concentric types), masseter, temporal and lateral pterygoid. Using myofunctional equipment as a facial exerciser, Chewytube ${ }^{\circledR}$ teethers (yellow, textured red and blue) with the dual purpose of working the chewing muscles, as mentioned in the previous section; this was done to gain volume and increase muscle mass of elongated tissues through distraction. At this stage, the use of a CEFAR Rehab X2 ${ }^{\circledR}$ electro-stimulator was also introduced in the post-surgical myofunctional treatment, using the TensBurst program (Transcutaneous electrical nerve stimulation) that causes rhythmic contractions to exercise the area and to gradually get the patient used to the sensations received to the next stage involved the use of a recovery program of small muscles using Neuromuscular electrical stimulation (NMES). The procedure consisted of applying TensBurst twice a day with an initial duration of 2' and gradually reaching 6' during a period of 1 week. At the beginning of the second week, the NMES program was introduced, proceeding in a comparable way.

\section{Postoperative arthroplasty (mobility recovery)}

From the 3rd day on, intensive recovery treatment was started with TheraBite $\AA$ using the 5-5-30 protocol, that is, the maneuver is performed 5 times per day, with 5 repetitions and a required completion time of 30 seconds, alternating with a pause of 30 seconds.

Once in the work sessions, we proceeded to assess the TMJ at the muscular and subcutaneous level, by means of manual therapy of the masseter, temporal, pterygoid, digastric and sternocleidomastoid, to check the loss of elasticity of the tissue. To do this, circles were made with the fingertips and displacement of the muscle masses. On the other hand, to assess condylar displacement, the index finger of each hand was placed in the space before the drink and the patient was asked to open and close her mouth in this position gently.

Progressively, the work intensified and joint elasticization techniques were introduced, to recover the physiological amplitude. Finally, retropulsion maneuvers were used. 


\section{Measurements and Results}

\section{Oral breathing \& Chewing-Swallowing (Efficacy)}

An asymmetry was detected in the expiratory marks, presumably an obstruction in the right part, which was diagnosed by the ENT, and a pattern of mixed breathing of the abdominal thoracic type was also verified, and in the frequent phases of abundant mucus a breathing pattern predominantly oral. In addition, the girl had an ogival palate and dental protrusion, which pointed to a pattern of oral respirator which was remitted to perform the adenoidectomy that allowed a correct nasal permeability and with the subsequent orthodontic and speech therapy treatments described above, getting the position of the tongue at rest and the respiratory type to be modified, also normalizing the position of the head as well as that of the shoulders.

Table 1.1. Comparative functional respiratory exploration between 3-16- years.

\begin{tabular}{|l|l|l|l|}
\hline & $\mathbf{3}$ years & $\mathbf{6}$ years & $\mathbf{1 2}$ years \\
\hline Respiratory Type & $\begin{array}{l}\text { Abdominal } \\
\text { Thoracic }\end{array}$ & $\begin{array}{l}\text { Abdominal } \\
\text { Thoracic }\end{array}$ & Costodiaphragmatic \\
\hline Respiratory mode & Oral-mixed & Mixed & Nasal \\
\hline Respiratory frequency & 27 & 23 & 18 \\
\hline Heart rate & $85 \mathrm{bpm}$ & $76 \mathrm{bpm}$ & $60 \mathrm{bpm}$ \\
\hline Nasal drainage & Asymmetric & Symmetric & Symmetric \\
\hline Nasal use allowance & Less than 1' & More than 1' & Penaf (-) \\
\hline Front head posture & Inclined & Inclined & Normal \\
\hline Lateral head posture & Forward & Forward & Normal \\
\hline Front shoulder posture & Normal & Normal & Normal \\
\hline Lateral shoulder posture & Inclined & Inclined & Normal \\
\hline
\end{tabular}

As seen in Table 1.1, the initiation of specific logopedic therapy after the surgery that began in the 2 nd phase of treatment provided some changes in nasal breathing parameters, since the patient eliminated the clavicular ascent and modified the anterior position of the shoulders and also acquired an adequate lip and tongue position at rest improving their fonorespiratory coordination. However, consolidation occurred on 3 rd.

The measures listed below in this screening protocol correspond to the records made in 2003, in the post-graft period and which correspond to the 1st phase, when the patient was 4 years old. However, we have been applied to the summary the Myofunctional Orofacial Exam model (MGBR) (Flores, Berretin-Felix, Beltrati y Queiroz, 2009) with the intention of showing the great utility of that evaluation instrument. 
Table 1.2. Evaluation of swallowing efficiency.

\begin{tabular}{|c|c|c|c|c|c|}
\hline $\begin{array}{l}\text { Regular } \\
\text { mastication }\end{array}$ & Alteration (X) & Functional ( ) & $\begin{array}{l}\text { Anatomical } \\
\text { TMJ () }\end{array}$ & Other ( ) & \\
\hline Incision & (0) Anterior & (1) Lateral & (1) Other & & \\
\hline Trituration & (0) Back Teeth & (1) Front Teeth & (1) Tongue & (0) Efficient & (1) Inefficient \\
\hline \multirow[b]{2}{*}{ Number of cycles } & Right (X) & 1st Portion & $\begin{array}{l}\text { 2nd Portion } \\
3^{\prime}\end{array}$ & 3rd Portion & $\begin{array}{l}\text { Average } \\
33 \%\end{array}$ \\
\hline & Left $(\mathrm{X})$ & $\begin{array}{l}\text { 1st Portion } \\
8^{\prime \prime}\end{array}$ & $\begin{array}{l}\text { 2nd Portion } \\
6^{\prime \prime}\end{array}$ & $\begin{array}{l}\text { 3rd Portion } \\
3^{\prime \prime}\end{array}$ & $\begin{array}{l}\text { Average } \\
100 \%-5 \%\end{array}$ \\
\hline Masticatory pattern & $\begin{array}{l}\text { (0) Alternated } \\
\text { Bilateral }\end{array}$ & $\begin{array}{l}\text { (1) Simultaneous } \\
\text { Bilateral }\end{array}$ & $\begin{array}{l}\text { (0) Preferential } \\
\text { Unilateral }\end{array}$ & $\begin{array}{l}\text { (2) } \\
\text { Chronic } \\
\text { Unilateral }\end{array}$ & \\
\hline Lip-seal & (0) Systematic & (1) Non-systematic & (0) Absent & & \\
\hline Speed & (0) Adequate & $\begin{array}{l}\text { (1) } \\
\text { Augmented }\end{array}$ & $\begin{array}{l}(0) \\
\text { Reduced }\end{array}$ & & \\
\hline Noisy mastication & (0) No & (1) Yes & & & \\
\hline $\begin{array}{l}\text { Unusual muscular } \\
\text { contractions }\end{array}$ & (0) Absents & (1) Presents & & & \\
\hline Masticatory time & $\begin{array}{l}\text { 1st Portion } \\
10^{\prime}\end{array}$ & $\begin{array}{l}\text { 2nd Portion } \\
14^{\prime}\end{array}$ & 3rd Portion 25' & $\begin{array}{l}\text { Average } \\
16,33^{\prime}\end{array}$ & \\
\hline \multicolumn{6}{|l|}{ Observations } \\
\hline Pain while chewing & (X) Absent & ( ) Right & ( ) Left & & \\
\hline Noisy TMJ & (X) Absent & ( ) Right & ( ) Left & & \\
\hline
\end{tabular}

It was observed that the patient ate and drank autonomously, with the presence of lingual lateral movements and with bolus propulsion without incidences in the pharyngeal phase. However, the patient presented an adapted masticatory pattern (due to the severity of her mandible alteration), preferably unilaterally, without lodging any remains in the buccal vestibule. The rotation movement was visible on the left, but on the right there was a mastication caused by microretrognathia and also restricted the movement of protrusion. The score obtained by the girl is 3 out of a maximum of 7 points, showing symptomatology compatible with lack of efficiency in swallowing, by the number of cycles and the duration of the same, as well as by the deficient crushing of the food.

\section{Soft tissue pre- and post-osteogenic post-distraction}

Table 1.3 Facial measures Pre/ Post 2nd - 3rd distraction

This table shows the comparison of the measures evolution between the different surgical timings.

\begin{tabular}{|l|l|l|l|l|}
\hline Facial measures & Pre & Jan 06 & Dec 08 & $\begin{array}{l}\text { N o v } \\
\mathbf{1 1}\end{array}$ \\
\hline Middle third of the face (glabella-subnasal) & 47 & 50 & 52 & 53 \\
\hline Lower third of the face (subnasal-gnatio) & 52 & 52 & 54 & 61 \\
\hline
\end{tabular}




\begin{tabular}{|l|l|l|l|l|}
\hline Face height & 97 & 104 & 106 & 114 \\
\hline Face width & 88 & 100 & 102 & 103 \\
\hline Outer ext. Eye right/lip right ext. & 54 & 60 & 63 & 65 \\
\hline Outer eye left/lip left outside & 63 & 65 & 65 & 67 \\
\hline Upper lip (subnasal to lowermost point of upper lip) & 15 & 20 & 20 & 21 \\
\hline $\begin{array}{l}\text { Lower lip (From the uppermost point of the infe- } \\
\text { rior lip to gnatio) }\end{array}$ & 25 & 27 & 30 & 40 \\
\hline
\end{tabular}
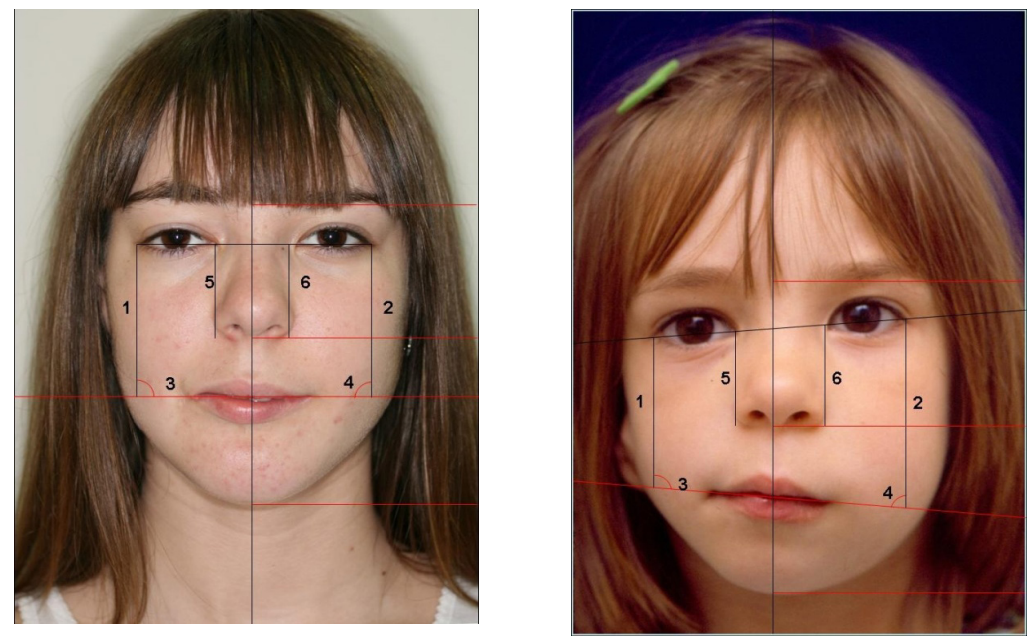

Figure 1. Comparison of frontal vision and symmetry.

Table 1.4 Comparative symmetry soft tissues

\begin{tabular}{|l|l|l|}
\hline Facial measurements & 2003 & 2015 \\
\hline 1. Distance edge ext.-right commissure (mm.) & 54 & 72 \\
\hline 2. Distance edge ext.-left commissure (mm.) & 63 & 71 \\
\hline 3. Angle commissure-edge ext. right & $86^{\circ}$ & $90^{\circ}$ \\
\hline 4. Angle commissure-edge ext. left & $93^{\circ}$ & $90^{\circ}$ \\
\hline 5. Right nasal height. (mm.) & 27 & 35 \\
\hline 6. Left nasal height. (mm.) & 30 & 35 \\
\hline
\end{tabular}

Currently, the patient presents adequate parameters (Table 3.1) in the frontal dimension (the height of the middle facial third oscillates between $46 \%$ and the lower third, 54\% respectively, vertical (upper lip between 19-22 $\mathrm{mm}$ and lower lip-chin between $38-44 \mathrm{~mm}$ ) as well as attaining symmetry, since the tracing of the two vertical tangents to the middle segment of the inner canthus of the eye coincides with the lateral nasal wing bilaterally and the measurements of the distance of each labial commissure to the midline drawn in the sub-nasal point they are symmetrical (Ferrer, 2009). 


\section{Post-surgical arthroplasty}

Table 1.5 Comparative evolution of ATM ankylosis.

\begin{tabular}{|l|l|ll|l|l|}
\cline { 2 - 6 } \multicolumn{1}{c|}{} & Aperture & Right-Left & Protrusion & Retrusion \\
\hline Pre-operative 2009 & $6 \mathrm{~mm}$ & $0 \mathrm{~mm}$ & $0 \mathrm{~mm}$ & $0 \mathrm{~mm}$ & $0 \mathrm{~mm}$ \\
\hline Post-operative2011 & $35 \mathrm{~mm}$ & $4 \mathrm{~mm}$ & $2 \mathrm{~mm}$ & $0 \mathrm{~mm}$ & $2 \mathrm{~mm}$ \\
\hline Actual 2015 & $35 \mathrm{~mm}$ & $7 \mathrm{~mm}$ & $3 \mathrm{~mm}$ & $0 \mathrm{~mm}$ & $3 \mathrm{~mm}$ \\
\hline
\end{tabular}

As shown in Table 3.2, not only has an adequate opening has been achieved and maintained, but also the range of lateral mobility as well as retrusion has been increased. The $35 \mathrm{~mm}$ measurement corresponds to the actual maximum aperture allowed by the pediatric TheraBite ${ }^{\circledR}$ device and the $45 \mathrm{~mm}$ adult version.

The results of post-surgical programs after distractions or after the arthroplasty would have required Surface Electromyography (sEMG) equipment or similar, to measure the gradual gains in strength.

\section{Conclusions}

The present work points out the importance of the application of an early treatment program from the early stages of childhood, initially based on the two vital functions: feeding (swallowing difficulties) and breathing (Caron, Pluijimers, Joosten, Mathijssen, Schroeff, Dunaway and Koudstaal, 2015). Madi, Shetty, Babu and Achalli, 2014); (Van de Lande, Caron, Pluijmers, Joosten, Streppel, Dunaway, ... \& Padwa, B. L. 2018); (Vila, Garmendía, Felipe, Suarez, Sánchez and Álvarez, 2010) as well as the need for a rigorous audiological follow-up of the baby to favor an adequate development of language, as well as the detection of difficulties in nasal permeability or a possible tubal dysfunction, which in short, allow the establishment of standardized respiratory and swallow patterns (Borras and Rosell, 2008) providing stability to the complex process of orofacial growth (Villanueva, 2014). On the other hand, further evidence is given for the importance of effective coordination between the maxillofacial surgeon, otorhinolaryngologist, orthodontist and the speech therapist in charge of the myofunctional work with the masticatory muscles. The state of these muscles greatly influences the development of the maxilla and the jaw, similar to the need to consider the state of the side contralateral to the AMH, according to Contreras and Yudovich (2014). Another unavoidable objective in the treatment of HFM is linked to recurrence, especially in severe pathologies such as ATM ankylosis (Gilda-Silva-Lopes and Luquetti, 2005) where postoperative myofunctional work will be decisive for the maintenance of the results obtained since hypomobility causes the retraction of the musculature and this favors bone resorption (Jayavelu, Shrutha, and Vinit, 2014). 


\section{Bibliography}

Borrás, S., y Rosell, V., (2006). Guía para la reeducación de la deglución atípica y trastornos asociados. Valencia: Nau Llibres.

Caron, CJJM, Pluijimers, BI, Joosten, KFM, Mathijssen, IMJ, van der Schroeff, MP, Dunaway, DJ, ... Koudstaal, MJ. (2015) Feeding difficulties in craniofacial microsomia: a systematic review. International journal of oral and maxilofacial surgery, 44 (6), $732-$ 737.

Contreras, C. y Yudovich, M., (2014.) Evolución de los sistemas de clasificación de microsomía hemifacial. Ortodoncia actual, 10 (39), $42-46$.

David, DJ., Mahatomarat, \& Cooter, RD., (1987). A multisystem classification. Plastic Reconstructive Plastic Surgery, 80, 525-535.

Ferrer Molina, Marcela (2009) La estética facial desde el punto de vista del ortodoncista. Madrid: Ripano, S.A.

Flores, K., Berretín-Felix, G., Beltrati, MI., \& Queiroz, I., (2009).Avaliaçao Miofuncional Orofacial- Protocolo MBGR. Revista CEFAC, 11 (2), 237-255.

Garliner, D. (1974). Myofunctional Therapy in Dental Practice: abnormal swallowing habits: diagnosis-treatment. Bartel Dental Book Co. (4) 222-223.

Gil-da-Silva-Lopes, V. L., \& Luquetti, D. V. (2005). Congenital temporomandibular joint ankylosis: Clinical characterization and natural history of four unrelated affected individuals. The Cleft palate-craniofacial journal, 42 (6), 694-698.

Horgan, JE, Padwa, BL, LaBrie, R., \& Mulliken, JB., (1995) OMENS-Plus: analysis of craniofacial and extracraniofacial anomalies in hemifacial microsomia. The Cleft palate-craniofacial journal, 32 (5), 405-512.

Jayavelu, P., Shrutha, SP., \& Vinit, GB., (2014). Temperomandibular joint ankylosis in children. Journal of Pharmacy \& Bioallied Science, Jul 6 (1), 178-81.

Madi, M., Shetty, SR, Babu, SG, \& Achalli, S. (2014). Hemifasyal Mikrozomi: Olgu Sunumu cinco Genel Bakis. Çukurova Universitesi Tip Fakultesi Dergisi, 39 (3), 625 - 635.

Mulliken, JB. \& Kaban, LB., (1987). Analysis and treatment of hemifacial microsomia in childhood. Clinics in Plastic Surgery. 14, (1), 91-100.

Ortíz, ML., Restrepo, DP. y Sierra, SY (2011) Análisis comparativo de la deglución normal y atípica utilizando la Técnica de Payne y la técnica convencional. CES Odontologia, 7 (1) 59-63.

Pruzansky, S., (1969). Not all dwarfed mandibles are alike. Birth Defects, 5, 120-129.

Suzuki, N., Miyazaki, A., Igarashi, T., Dehari, H., Kobayashi, J. I., Miki, Y. \& Hiratsuka, H. (2017). Relationship Between Mandibular Ramus Height and Masticatory Muscle Function in Patients with Unilateral Hemifacial Microsomia. The Cleft Palate-Craniofacial Journal, 54 (1), 43-52.

Van de Lande, L. S., Caron, C. J., Pluijmers, B. I., Joosten, K. F., Streppel, M., Dunaway, D. J., ...\& Padwa, B. L. (2018). Evaluation of Swallow Function in Patients with Craniofacial Microsomia: A Retrospective Study. Dysphagia, 33 (2), 234-242.

Vento, AR., Labrie AR \& Mulliken, JB., (1991). The OMENS classification of hemifacial microsomia. The Cleft Palate-Craniofacial Journal, 28, 68-76

Vila, D., Garmendia, G. y Felipe, AM., Suarez, F., Sánchez, E. y Álvarez, B., (2010).

Aplicación de distracción osteogénica mandíbular en niños con el síndrome de apnea obstructiva del sueño. Revista Cubana de Estomatología, 47 (1), 37-49. Enero-Marzo. 